\title{
Preaching Prophets: Upton Sinclair and The Moslem Sunrise
}

\section{Steven Bembridge}

\section{(2) OpenEdition \\ Journals}

Electronic version

URL: https://journals.openedition.org/ejas/13140

DOI: 10.4000/ejas.13140

ISSN: 1991-9336

Publisher

European Association for American Studies

Electronic reference

Steven Bembridge, "Preaching Prophets: Upton Sinclair and The Moslem Sunrise", European journal of American studies [Online], 13-2 | 2018, Online since 19 July 2018, connection on 08 July 2021. URL: http://journals.openedition.org/ejas/13140 ; DOI: https://doi.org/10.4000/ejas.13140

This text was automatically generated on 8 July 2021.

Creative Commons License 


\title{
Preaching Prophets: Upton Sinclair and The Moslem Sunrise
}

\author{
Steven Bembridge
}

\section{MUFTI MUHAMMAD SADIQ AND THE MOSLEM SUNRISE}

1 The relationship between Islam and America is an important political and social issue. The rise of Islamophobia is an alarming feature of a society in which misunderstanding and misinformation can sometimes dominate good sense. The conflicting opinions of Barack Obama-who recognised America's long association with Islam-and Donald Trump-who called for a ban on all Muslims entering the United States-capture the extremity of viewpoints that have recently manifested in America (Obama; Trump). In the history of American Islam, the turn of the twentieth century saw a significant number of Muslims arrive in the United States. Census data is unreliable to provide an exact figure, but an estimate of around sixty thousand does appear in the literature (GhaneaBassiri 136). We do know, though, that peoples from Albania, Bosnia, Syria, Turkey, and India-each with significant Muslim populations-all chose to settle in America (137).

2 We also know that in February 1920, an Islamic missionary called Mufti Muhammad Sadiq arrived in New York. Philadelphia's Evening Public Ledger reported that Sadiq was "here to teach the doctrine of Ahmadi, a reformed Mohammedanism" (Evening Public Ledger). Sadiq would return to India in September 1923 after converting over seven hundred Americans to Islam (Turner 130). Ahmadiyya Islam's first contact with the United States, though, had actually occurred a few years earlier through the work of Mohammed Alexander Russell Webb (1846-1916)-America's first Anglo-American convert to Islam and representative for Islam at the World's Parliament of Religions of 1893, Chicago (Turner 121). Webb had even established a relationship with Sadiq before Sadiq arrived in America (Abd-Allah 60; Green 217). Both Webb and Sadiq preached a variation of Islam derived from the teachings of Mirza Ghulam Ahmad (1835-1908), the Ahmadi spiritual leader. Unlike orthodox Muslims-who believe that Muhammad ibn 'Abd Allah (570-632) was the final messenger of God-Ahmadi Muslims believe that 
Ahmad (1835-1908) fulfilled this role. Ahmad even went as far as to view himself as a likeness of the Messiah, just as Jesus had purported himself to be.

Sadiq initially went to America to bring the message of Islam to all, but he soon found that white middle-class America-amongst whom Webb had previously worked-was not as willing to entertain the idea of Islam as he first thought (Turner 124). Sadiq began to find an affinity in the experiences of African Americans because he regarded Islam as an "antiracist religion" (Howell 53). The work of Sadiq resonated closely with the work of the Muslim, pan-Africanist, Duse Mohammed Ali (1866-1945)-who worked with Marcus Garvey's (1887-1940) Universal Negro Improvement Association (UNIA) (Turner 81). Through his own association with the UNIA, Sadiq began to see his version of Islam-which itself challenged Christianity in British-ruled Punjab-as a solution to the inequalities that affected black Americans (GhaneaBassiri 208, 211). An important legacy of Sadiq's mission was his founding of the The Moslem Sunrise in 1921. Its aim was to communicate the message of Islam to prospective converts and to America's growing Muslim community. ${ }^{1}$ It also became a means through which to attack misrepresentations of Islam that appeared in America's media (Turner 121). The Southern Herald, for example, had previously written of the "Amazing Spread of Islam" in language that was clearly meant to unsettle its readers. Phrases such as "militant followers," "fanatic zeal," and "blind fanatics" sit uncomfortably with a detailed exposition of the Islamic world (Southern Herald). Webb even stated that "there is no system that has been so wilfully and persistently misrepresented as Islam, both by writers of so-called history and by the newspapers and press" (996).

4 In October 1922, The Moslem Sunrise included a brief review of Upton Sinclair's short story "They Call Me Carpenter," which appeared in serialized form in Hearst's International from July to October of that year. "They Call Me Carpenter" begins in Western City, a thinly veiled Los Angeles. Billy, a member of high society and war-hero, receives a beating at the hands of a mob of nationalists and ex-servicemen. He seeks refugee in St. Bartholomew's Church, and, while he shelters there, Jesus-the titular Carpenter-descends from a stained-glass window to heal him and to seek his assistance in the modern world. The twentieth century has such a profound effect on Carpenter that he ultimately abandons the redemptive death that sits at the core of Christianity: "I meant to die for this people! But now - let them die for themselves!" he derides ("Carpenter," Oct. 140). The story closes with the image of Carpenter running back to the church screaming "Let me go back where I was - where I do not see, where I do not hear, where I do not think! Let me go back to the church!" ("Carpenter," Oct 140).

5 The review article that appeared in The Moslem Sunrise was entitled "Jesus and the Modern Christians," and it opened with the following:

A new serial story from the pen of the famous novelist, Upton Sinclair, is appearing in Hearst's International. It is the story of Jesus in the modern life and illustrates what Jesus will say to the Christians of the day if he appears among them and how will the Christians treat him. We give below a few sample lines out of it. It is only a fiction but well shows which way the wind blows.

(TMS “Modern Christians" 137)

6 The article concentrated on two themes: Christ and society and Christ and the Church. Under the heading "what the modern Christians say of Jesus among them," The Moslem Sunrise argued that society would view Jesus as a threat to its very structure if he should return to contemporary America (TMS "Modern Christians" 137). Two quotes 
that they included explicate this theme well. The first was "we shall be mistaken if the order-loving and patriotic people of our Christian community do not find a way to stamp their heel upon this vile viper [Carpenter] before its venom shall have poisoned the air we breathe" ("Carpenter," Sept. 40). The second quote was "[Carpenter is] an anarchist plotting to let loose the torch of red revolution over this fair land" (Carpenter," Sept. 39). Under the heading "what Jesus says to modern Christians (especially Christian ministers)," The Moslem Sunrise turned its attention to the relationship between Christ and the modern Church with the following words of Carpenter: first, "my house shall be called a house of prayer, but ye have made it a den of thieves. He that steals little is called a pickpocket, but he that steals much is called a pillar of the Church" (Carpenter," Sept. 41); and second, "the theologians and scholars and pious laymen fill the leisure class churches" (Carpenter," Sept. 43).

7 At first sight, the choice of The Moslem Sunrise to include Sinclair's work may seem a little conspicuous. Hearst's International-which would merge with Cosmopolitancertainly contrasted with the clear Islamic message of The Moslem Sunrise. In the November issue of 1922, one article entitled "Clouds in the East" even warned of the "militant religion" of Muslims and the threat of an "Islamic bloc" (Clouds," Nov. 7). However, a closer look at Sinclair's life and literary legacy begins to elucidate an affinity that The Moslem Sunrise found in the work of Sinclair. Turner suggests that by 1921, Sadiq had become an "angry opponent of white mainstream Christianity" in America (123), so, too had Upton Sinclair. He is one of American Literary naturalism's most important figures. Naturalism emerged in the late nineteenth century, and recent critical approaches to the genre regard it as a literary response to "the tension between older, traditional belief systems and the new science of the post-Darwinian nineteenth century" (Link 2). Mark Knight and Thomas Woodman have recently argued that supposedly secular novels "may well address quite technical matters of religious doctrine"-writers apparently disassociated from religious themes often "explore the specifics of theology" (3). Sinclair is one such author. He left the Church at age sixteen after growing unease and undergoing struggles with Christological concepts that lead him to question Christian dogma (Arthur 10). And yet, in A Personal Jesus (1954), Sinclair states that "I have never left Jesus" (viii). He wrote the work as an expression of his lifelong devotion to the historical figure of Christ. Jesus for Sinclair was not the divine Son of God common to American evangelicalism; he was a human whose teachings were responsible for "molding" Sinclair's own "revolutionary attitude towards the world" ("What Life Means to Me" 592). Sinclair was, of course, an ardent socialist.

8 The Jungle (1906) is perhaps Sinclair's greatest literary legacy that expresses his socialism. It charts the life of the Lithuanian immigrant Jurgis Rudkus and his family who fall victim to the forces of capitalism in Chicago's meatpacking factories. It is also a novel that reveals Sinclair's relationship with Christ and his contemporary Church. Sinclair writes of "the stygian midnight of American evangelicalism" and the "final death struggle" between socialism and the church (398). Christ becomes a "classconscious workingman," a "union carpenter," an "agitator," a "law-breaker," and an "anarchist" (399). A few years later, Sinclair would write Samuel the Seeker (1910), which is an allegorical novel that exposes a naïve farm boy to capitalist America. Sinclair again refers to Christ and writes that "what has this money scramble to do with the teaching of Jesus?" (247). He argues that Jesus "was a man, like you and me! He was a poor man, who suffered and starved! And the rich men of His time despised Him and 
crucified Him!" (263). Early in his career, then, Sinclair presents Christ as a human, socialist rebel who existed in a state of conflict with established orthodoxy.

Sinclair was important to The Moslem Sunrise because here was a white, socialist of Christian heritage-a "famous novelist"-who shared a very real grievance against the Christian Church and the Christ that they taught. Through him, The Moslem Sunrise could bring greater legitimacy to their own interpretation of Islam, as they sought to spread its message across America. Remember, too, that the Ahmadi Islam that Sadiq knew had a built-in expectation of prophetic continuation, which is an important theme for understanding "They Call Me Carpenter." Works like the The Jungle revealed that Sinclair was interested in the plight of immigrants and that he also wrote about a Christ who was unafraid to challenge American society. As we shall see, Sinclair's concept of Christ was also part of a much larger cultural conversation that centred upon Christ's masculinity and ethnicity and which The Moslem Sunrise and Sinclair both addressed in their work. Stephen Prothero and Richard Fox demonstrate the importance that the figure of Jesus has had in the development of American culture. Indeed, the subtitles of both their works provide a clear sense of the cultural importance of Jesus-Fox describes him as a "Cultural, National Obsession" (24), and Prothero refers to him as a "National Icon" (16). The processes that lead to the affinity that The Moslem Sunrise found in Sinclair were different, but they each contributed to the cultural legacy of Christ with a cultural purpose that created a moment of unity.

\section{THE PROPHET JESUS IN NINETEENTH CENTURY AMERICA}

10 In order to understand the spirit of unification that Upton Sinclair and The Moslem Sunrise shared, it is first necessary to understand the historical context of just who Jesus was for both Muslims associated with The Moslem Sunrise and Sinclair himselfthereby revealing the first major theme of why The Moslem Sunrise turned its gaze towards Sinclair. The Qur'an's Surah Al-Baqarah (The Cow) 2:285 lays out Islam's understanding of Jesus. It states that he was no different from other messengers of God, or prophets, who had gone before him. Jesus for Muslims is not God; he is a human prophet. America had long had a close relationship to the notion that Jesus may not have been the divine son of God that stretches back to the Enlightenment and to the First Great Awakening (1730-1755). New England Deists and Unitarians, for example, actively rejected orthodox teachings that Jesus was the Son of God. In 1813, Thomas Jefferson (1743-1826) retold the Gospels in The Life and Morals of Jesus of Nazareth, or the Jefferson Bible. He removed all references to the supernatural aspects of the life of Jesus, and he closed the work with "there laid they Jesus, and rolled a great stone to the door of the sepulcher, and departed"-a human end for a human prophet (Jefferson 132).

11 William Ellery Channing (1780-1842) -a leading figure of the American Unitarians-also laid out in the "Baltimore Sermon" the cornerstones of Unitarian beliefs and practices. He protested "against the irrational and unscriptural doctrine of the Trinity" and regarded the nontrinitarian viewpoint as a closer reflection of "primitive Christianity" (9). Arguing that "there is one God, even the father," Channing rejected the notion that Jesus was God and believed that "the father alone is God" (9). The legacy of the enlightenment was alive and well in early twentieth-century America. Robert Ingersoll (1833-1899) - a celebrity orator who regularly attacked religious orthodoxy-would write that "when Paine was born, the world was religious, the pulpit was the real 
throne, and the churches were making every effort to crush out of the brain the idea that it had the right to think" (Ingersoll 138).

The Moslem Sunrise also referred to America's religious heritage to explicate its own theology to Americans in a way that they could understand, or, at the least in a way that would be familiar to some of them. The July 1922 issue included an article entitled "Muhammadan Faith Explained." It stated that "the Moslems do not worship Muhammad. Muhammad is only a man and messenger of God. We worship God alone. One God like the Jews and Unitarian Christians believe" (TMS "Faith" 118). However, it also included articles that unfairly condemned Paine and Ingersoll for their perceived opposition to all forms of religious expression. For example, C. F. Sievwright, or Muhammad Abdul Haqq-an Australian convert to Ahmadi Islam-wrote that "atheism is rather in the lip than in the head or heart of Man even as Bob Ingersoll, Tom Paine, Voltaire and others alone knew full well" (Sievwright "We Must Co-Operate" 145).

Jefferson and Channing, then, shared with Islam a similar understanding that Jesus was a human prophet, but they were not Muslims. Jefferson saw in Unitarianism and Deism a close affinity with Islam, but his own relationship to the Islamic faith fluctuated between public admonishment and occasional private sympathy (Spellberg 236-237). Channing had also described what he regarded to be the falsity of Islam (Infidelity 26). As the nineteenth century developed so, too, did the theological culture that would impact Sinclair's conception of Christ and which also continued to resonate with an Islamic understanding of Jesus. Higher biblical criticism was one such force. It refers to the method of viewing the Bible as an historical artefact in terms of its authorship, chronology and origin (Soulen and Soulen 154). Two individuals elevated its widespread influence in the United States: David Friedrich Strauss (1808-1874) and Ernest Renan (1823-1892). Strauss's Das Leben Jesu (1835) did not deny the existence of Jesus, but it did separate the life of Jesus from the centuries of tradition that surround it. Strauss's Jesus is not God; he is a human being devoid of any divine support or supernatural mission (780). A quarter of a century later the French philosopher and historian Ernest Renan published the best-selling La Vie de Jésus (1863), The Life of Jesus. Renan clearly stated that Jesus was not God, writing that "Jesus never dreamed of making himself pass as an incarnation of God" (154). Muslim scholars of the nineteenth century were certainly familiar with the work of Strauss and Renan, and they would incorporate it into their own exploration of Christianity (Jung 25).

14 Moreover, the very foundations of Ahmadi Islam resonate with an alternative understanding of Jesus that resonates with the work of Strauss and Renan. Ahmad preached that Jesus did not die upon the cross but survived. Jesus would then travel to Kashmir where he spent the remainder of his life teaching until he died at the age of 120 years old (Jung 25). In July 1922, The Moslem Sunrise itself published a review of literature concerning theories surrounding the death, or apparent death, of Jesus upon the cross. They concluded that "he could not have died,--hence he underwent a condition of suspended animation or merely swooned" (TMS "Jesus Was Crucified" 118). Look to Strauss and Renan, and the same uncertainty about Jesus' death and resurrection exits. The examples below first show Strauss's repudiation of Christ's death upon the cross and then Renan's interpretation of Christ's resurrection as a product of Mary Magdalen's imagination:

The short time that Jesus hung on the cross, together with the otherwise ascertained tardiness of death by crucifixion, and the uncertain nature and effects of the wound from the spear, appeared to render the reality of the death doubtful. 
(Strauss 737)

In the absence of contradictory documents this can never be ascertained. Let us say, however, that the strong imagination of Mary Magdalen played an important part in the matter. Divine power of love! Sacred moments in which the passion of one possessed gave to the world a resuscitated God! (Renan 272)

Sinclair was undoubtedly aware of Strauss and Renan's influence upon the landscape of America's theological history. In The Cry For Justice: An Anthology of the Literature of Social Protest (1915) -an edited collection of writings from a number of different sourcesSinclair includes a chapter devoted to Jesus that draws from Renan's La Vie de Jésus (350). In A Personal Jesus-itself a culmination of Sinclair's exploration of the historical Christ-he includes a passage that resonates with the spirit of Strauss's earlier higher biblical criticism. Sinclair writes that "all that we have is a set of records, put down long afterwards, based upon tradition. The texts are highly suspect, and every statement must be critically examined, every word must be studied with care" (81). Both Ahmadi Muslims and Upton Sinclair, therefore, each approached the historical Jesus with alternative understandings based on their own respective religious orthodoxies.

Neither The Moslem Sunrise nor Upton Sinclair would have viewed the other as representing their own theological position per se, but there certainly did exist between them a homogeneous understanding of the humanity of Christ. Although Sinclair does not concentrate upon Jesus' humanity in "They Call Me Carpenter" to such an extent, the very human characteristics that Carpenter shows at the end of the work are suggestive of this much broader theme common to Sinclair's body of work-Carpenter's face becomes "contorted with fury," as he shakes the dust off his feet upon those that deny him ("Carpenter," Oct. 140). Moreover, in the novel They Call Me Carpenter, Sinclair, like Strauss, even questions supernatural explanations of miracles. He prefers instead to view them as a piece of "stage management" (110-111). That being said, the choice of The Moslem Sunrise to include a review of "They Call Me Carpenter" starts to make a little more sense if we view both Sinclair and The Moslem Sunrise as sharing a common Christology-albeit a Christology that emerges from quite different sources.

\section{SOCIAL ACTIVISIM AND THE TEACHINGS OF CHRIST}

The work of Renan also influenced the way in which Sinclair thought about the relationship of Christ's teachings to society. American socialists often interpreted Renan's work as "devoted to the cause of the disaffected and the dispossessed" (Burns 15). For them, Renan's Jesus was the leader of the first socialist party, and they would cite the following text to substantiate their position:

The founders of the kingdom of God are the simple. Not the rich, not the learned, not priests; but women, common folk, the humble, and the young. The great sign of the Messiah's coming is that "the poor have the good tidings preached to them." It was the idyllic and gentle nature of Jesus that here resumed the upper hand. A great social revolution, in which distinctions of rank would be dissolved, in which all authority in this world would be humiliated, was his dream. (Renan 82)

Sinclair's incorporation of Renan into The Cry For Justice-which appears in a chapter entitled "Jesus"-refers to Jesus as a member of the working classes who held no sway with the political elite (350; Renan 117-118). Other chapter titles such as "Toil," "Mammon," and "Socialism," also define the tone of the collection $(37,485,783)$. Sinclair's association with an often quite radical socialism-which he targeted against 
the Christian Church-establishes the second sympathy that The Moslem Sunrise found in his work. The Socialist Party of American (SPA) that Upton Sinclair joined in 1904 was a hotbed of theological discussion; it almost became a religious movement in its own right (McKanan 751). At the time of Sinclair's membership, the SPA's leading light was Eugene V. Debs-who helped found the Party in 1901. His socialism had a profound influence upon Sinclair, who would even play the role of Debs in the film of socialist propaganda, The Appeal to Reason (1914) (Arthur 156). In Labor and Freedom (1916), a collection of his own writings, Debs revealed the close affinity between the SPA and the conception that Jesus was not divine. He claimed that "Jesus was not divine because he was less than his fellowmen but for the opposite reason he was supremely human" (23). Debs viewed Christ's teachings through the socio-political culture of America and concluded that "pure communism was the economic and social gospel preached by Jesus Christ" (26).

Consequently, Sinclair's rendering of Christ in "They Call Me Carpenter" portrays the figure of a socialist agitator. Carpenter preaches that "if a man pile up food while others starve, is not this evil?" (Carpenter," Aug. 128). Preaching in the streets, Carpenter cries out "Woe unto you, doctors of divinity," as he attacks "the leisure class churches" who should practice the teachings of Christ rather than loading "the backs of the working-classes with crushing burdens" ("Carpenter," Sept. 43). Upon Carpenter's arrest towards the end of the story, an angry crowd also labels him the "Red Prophet" ("Carpenter," Oct. 140). In the version of They Call Me Carpenter (1922) that became the novel, Sinclair extends the abuse that Carpenter receives to include such terms as "the Bolsheviki prophet," "goddam Arnychist," and "I won't work! I won't work!"-which was a common derogatory sobriquet for the Industrial Workers of the World (IWW) (214). The IWW was a labour union that Eugene Debs helped found in 1905. In the appendix, Sinclair even refers to The Call Me Carpenter as "a literal translation of the life of the world's greatest revolutionary martyr, the founder of the world's first proletarian party" (224). The Moslem Sunrise could not have failed to notice that Sinclair was an author with very a real grievance against the Church's teachings of Christ.

Indeed, GhaneaBassiri states that, during the 1920s, Muslims became increasingly political, and they began to found associations to "meet the religious and social needs" of their communities (172). In April 1922, under the banner "Significant Sayings of the Famous Men of the Day"-which was a regular feature-The Moslem Sunrise cited an interview of Arthur Conan Doyle that the Chicago Daily Tribune undertook. Doyle stated that "the bishops and deans-the lot of them-ought to wear a sackcloth and ashes, because they represent an organization that has failed" (qtd. in TMS "Significant," Apr. 97). Doyle was actually promoting Spiritualism as a religion that "will sweep the earth," but The Moslem Sunrise clearly found an affinity in his blatant attack upon the clergy (Chicago Daily Tribune). It also included part of a report from The Detroit Free Press in which one Rev. B.[W.] Pullinger-who was addressing an automotive union meetingclaimed that "we've got to live for others" ("Church Has Failed, Says Rev. Pullinger" 2). Pullinger wrote that "the church has failed to touch the average man; it has catered to class and sentimentalized too much" (qtd. in TMS "Significant," Apr. 98; "Church Has Failed, Says Rev. Pullinger" 2).

21 An inclusion from Louis E. Rowley-biographer of Mary C. Spencer (1842-1923), Librarian at Michigan State Library-demonstrated these same concerns further. 
Rowley claimed that "the church has been the militarist government's most powerful recruiting agency ever since it became an organized social force in the state" (qtd. in TMS “Significant," Apr. 97). Sinclair's socialism and The Moslem Sunrise's attacks upon the Church and its leaders, therefore, demonstrate a sympathy between both parties. They each viewed the relationship between the Church and the society to which it ministered as fractured and in need of reform, but the means of that reform were quite different. Sadiq aimed to convert Christians to Islam, but Sinclair aimed for a greater manifestation of political purpose.

\section{THE SOCIAL GOSPEL AND HUMAN BROTHERHOOD}

Perhaps a more significant clue as to why The Moslem Sunrise included the work of Sinclair emerges from the work of the Social Gospel. It purported that the least able in society were becoming increasingly disempowered in the organism-like cities of Chicago and New York-the very context from which naturalism emerged. It soughtthrough the leadership of such key figures as Washington Gladden (1836-1918) and Walter Rauschenbusch (1861-1918) - to apply the teachings of Christ to society. The Social Gospel became known for its promotion of the "Fatherhood of God" and the "Brotherhood of Man." These concepts encapsulated the notion that humanity must abandon individualism and work together for the betterment of society (McLoughlin 160). Rauschenbusch himself clearly stressed the importance of brotherhood and its redefinition within the bounds of both Christianity and socialism. He claimed that:

It would be no betrayal of the Christian spirit to enter into a working alliance with this great tendency toward the creation of cooperative and communistic social institutions based on the broad principle of the brotherhood of men and the solidarity of their interests. (Rauschenbusch 400)

Sinclair explored the link between American socialism and the Social Gospel in The Cry for Justice through the incorporation of Rauschenbusch's Christianity and the Social Crisis (1907). He included an analysis of Christ's teaching that regarded service to others as being more important to God than service to oneself (346). The spirit of the Social Gospel emerges in "They Call Me Carpenter." Billy defends the actions of Carpenter to a reporter by claiming that "Mr. Carpenter is not a radical; he is a lover of man ... how came it that phrases of brotherhood and love have come to be tainted with radicalism? ... he teaches brotherhood" (Carpenter," Aug. 29). The spirit of brotherhood was just as important for The Moslem Sunrise. The Qur'an's Surah Al-Hujurat (The Chambers) 49:10 stresses the importance of a brotherhood of believers within Islam, and Sadiq married the concept with an oppositional relationship to Christianity. He wrote that "Christianity cannot bring real brotherhood to the nations ... join Islam, the real faith of Universal Brotherhood which at once does away with all distinctions of race, color and creed" (TMS "True Salvation" 267).

Numerous other articles appear throughout the Moslem Sunrise that refer to the concept. One Henry S. Wilcox wrote to Sadiq and thanked him for creating a "worldwide human brotherhood" (TMS "Some Appreciations" 19). The journalist Qazi A. Latif also referred to Islam as having "every virtue of Socialism ... Islam preaches equality and brotherhood" (TMS "America" 122). Sinclair's "They Call Me Carpenter," therefore, certainly resonates with the notion of brotherhood common to Islam. True, the concept for The Moslem Sunrise and Sinclair are distinct, but Latif's conflation of socialism and Islam goes some way to explain a commonality of spirit that The Moslem 
Sunrise found in Sinclair's work. That being said, Sinclair's ideas of Brotherhood were often tainted with prejudice, particularly against certain immigrant communities, as was American socialism (Leinenweber). Indeed, Turner has also noted that Sadiq himself demonstrated an inconsistent view of equality with regards to racism within the Muslim world (122).

Sinclair wrote in an America that was in the process of exploring a more pluralist approach to immigration. Horace Kallen (1882-1974) called for a "symphony of civalization" (220), and Randolph Bourne (1886-1918) rejected "Americanization" in favour of a "trans-nationalism" (96). Sinclair may well have treated the experiences of Lithuanian immigrants in The Jungle with a sensitivity that appears to reject nativism, but critics have also noted his use of pejorative language to describe immigrant communities such as Greeks, Romanians, Sicilians, and Slovaks (Elliot 42). Katrina Irving reads Sinclair's The Jungle as a work that represents “anxieties about America's racial future" (50). She also extends her analysis to naturalism more broadly and criticises Stephen Crane's (1871-1900) Maggie: A Girl of the Streets (1893), and Frank Norris's (1870-1902) McTeague: A Story of San Francisco (1899) for a "nativist perception [of] immigrant women" as an "active agent of racial degeneration" (6).

Moreover, Sinclair's casting Russians, Mexicans, and Irish immigrants as Carpenter's disciples, does not actually ennoble them. It almost exploits them as exemplars of low status members of society from which Christ would have drawn his followers. The language that Sinclair uses to describe Mexicans and Italians in They Call Me Carpenter is also troubling, even if the words are the narrative voice of the novel's protagonist (73). Billy refers to an immigrant neighbourhood as a "crowded slum quarters, swarming with Mexicans and Italians and other foreigners" (68). It is worth noting, too, that this same passage does not appear in "They Call Me Carpenter," so we cannot be sure if The Moslem Sunrise was aware of Sinclair's ambiguous relationship to immigrants (Carpenter," Aug. 24).

Sadiq, though, was certainly aware of the effects of discrimination because he himself had become a victim of the Immigration Act of 1917. It prohibited certain classes of people from entering the United States, including alcoholics, criminals, and the sick (U.S. Department of Labor). Sadiq was initially refused entry to the United States when he arrived there in 1920 (Turner 115). In April 1922-in the issue preceding the review of Sinclair's work-The Moslem Sunrise responded to Sadiq's treatment with an article entitled "If Jesus Comes to America" (TMS “America" 85). The title of the article also demonstrated that The Moslem Sunrise was willing to explore American popular culture if it served the greater purposes of Sadiq's Islamic mission. Emerging from the Social Gospel-which was most influential between 1880 and 1920 (Dorrien 187)-William Stead's If Jesus Christ Came to Chicago (1894) and Edward E. Hale's If Jesus Came to Boston (1895) show a clear titular similarity. Stead imagined the direct application of the teachings of Jesus in modern times and described how the novel attempted "to illustrate how a living faith in the Citizen Christ would lead directly to the civic and social regeneration of Chicago" (xiv). Hale built upon the work of Stead and provided a similar rendered in a new location (Higgs 252). The Moslem Sunrise extended the work of the Stead and Hale, however, to speak directly to the experience of immigrant communities.

"If Jesus Comes to America" opens with the following challenge: "if the blessed Jesus, whose body rests in peace in Sirinagar ... had been alive in these days and had fancied 
over to America, how would he have been treated by the immigration department?" (TMS "America" 85). Having just arrived in America, then, Jesus faces an immigration interview, but he is refused entry. Both referring to and satirising the 1917 Act, Jesus cannot enter the United States because "he comes from a land which is out of the permitted zone," "he is not decently dressed," "he believes in practising the Law of Moses which allows Polygamy [sic]" (TMS "America" 86). Jesus' last words are "I shake off the dust of my feet and go back to the charming land of Hindustan" (86).

The Moslem Sunrise, then, used the figure of Jesus returned to comment upon the unfair treatment of immigrants, but the very nature of the narrative demonstrates just why they would have found "They Call Me Carpenter" so relevant when they learned of its publication-it, too, explored the 'immigration' of Christ of America. The climaxes of the article and Sinclair's work are also remarkably similar: Jesus leaves the America that he discovers, although only in Sinclair's story does he take agency upon himself to do so. The Ogden Standard-Examiner caught the implication of "If Jesus Comes to America" and included it in a larger article about Sadiq. They concluded that The Moslem Sunrise contains "numerous articles comparing Mohammedanism with Christianity, and always, of course, to the great disparagement of the latter" ("Trying to Make Christian America Mohammedan" 8). It is not hard to see why The Moslem Sunrise would have found Sinclair's willingness to incorporate immigrant communities into his fiction laudable-but, as we shall see, the issue of race for Sadiq and Sinclair is challenging and even relates to the figure of Christ himself.

\section{MASCULINITY, THE CHURCH, AND JESUS}

30 Closely related to the notion of brotherhood was the Social Gospel's relationship to muscular Christianity. It contributed to a concerted effort to masculinise the image of the feminized Church that Ann Douglas explored in her seminal work (Douglas). Clifford Putney argues that "the issue of unmanliness in religion" was central to the Social Gospel in its adoption of muscular Christianity (42) - a trans-denominational movement that "hoped to energize the churches and to counteract the supposedly enervating effects of urban living" (1). Young men found that the feminized version of Christianity in the churches that they attended and in the literature that they read was no longer viable for the demands of an industrialized and individualist society (Douglas 115). Existing in a complementary relationship to the manliness of Christ's followers was the masculinity of Christ himself as seen in artistic representations.

In Moby Dick (1851), for example, Herman Melville alluded to common nineteenthcentury representations of the feminised Christ that had become entrenched in American culture and against which the Social Gospel reacted. Melville wrote that whenever artists attempted to represent "the divine love in the Son," they naturally painted "the soft, curled, hermaphroditical [Christ of] Italian pictures" (418; Prothero 91). Kate P. Hampton, writing for The Outlook in 1899, even surveyed the clergy in response to her question "does the face of Christ, as depicted in ancient and modern art, realize your idea of a strong face?" (735). The responses were telling. The Rev. Charles Cuthbert Hall of the Union Theological Seminary stated that "the great artistic types of the Christ face constantly disappoint me by the lines of weakness and morbid emotionalism" (qtd. in Hampton 744). The Unitarian minister, Rev. John W. Chadwick of Brooklyn, was more adamant. He stated that "I could answer the question in one word, "No"” (qtd. in Hampton 736). 

out in the Christian Church. It capitalised on the crisis as a means of establishing what it believed to be the superiority of Islam over Christianity. In October 1922, it included a news item from a British vicar-Rev. B. G. Bourchier-who claimed that the Church's "masculine following is decreasingly rapidly" and that the fault must lie with the clergy with "their weak and feeble personalities" (qtd. in TMS "Significant," Oct. 152). In contrast to the perceived effeminacy of Christianity, The Moslem Sunrise reprinted an article that first appeared in The Negro World-the mouthpiece of the UNIA-which stressed that Islam was a religion that taught its "followers to be manly, selfrespecting, charitable, [and] ambitious"-which was "unlike his Christian brother" (TMS “Crescent or Cross?" 263). The Rev. Pullinger's address to the Detroit auto workers also captured the spirit of the masculine Christ. He pleaded "for a stronger type of Christian man, a man more like the strong, virile, fine man that Christ was" ("Church Has Failed, Says Rev. Pullinger" 1).

The relationship between masculinity and naturalism is also a well-researched area. John Dudley explores the "masculinist discourse of the Progressive Era" as an "essential element in the formation of American literary naturalism" (Dudley 14). Dudley refers to a number of manifestations of male resistance to a culture of aesthetics-one of which, he argues-was muscular Christianity (9). Donna Campbell also refers to naturalists such as Stephen Crane and Frank Norris as instigating a "backlash against what was perceived as feminine domination of audience and literature" (47). Derrick Scott has even approached The Jungle as an exemplar of a naturalist paradox: it defends against female power whilst also creating it (94), and it also depicts "male disintegration ... to generate new forms of confining masculine power" (98). Sinclair's adoption of the journalistic mode in The Jungle could even be viewed as an act of bringing greater masculinity to the profession of writing for a living (Dudley 7; Wilson 114). Sinclair, then, was certainly willing to explore the masculinist discourses of his generation.

In "They Call Me Carpenter," though, he directly responds to the issue of perceived unmanliness in both members of the Church and Christ himself through the characterisation of James-who in the Bible is the brother of Jesus. The reader learns that James wears the "clothes of a working-man ... he was something of an agitator" (Carpenter," Aug. 30). "I am a Christian," he states, "one of the kind that speak out against injustice ... I can show you Bible texts for it ... I can prove it by the word of God" (30). The characterisation of James would not seem so out of place in The Jungle-he resembles the socialist agitators that Jurgis meets in the final stages of the novel. James belongs to no church, but he does belong to the brotherhood of workers-a church in which he can participate. James also bears "a striking resemblance to carpenter" (Carpenter," Aug. 30), and Sinclair refers to him as "James, the carpenter" on a number of occasions (Carpenter," Oct. 32). James is "the carpenter with a religious streak" (Carpenter," Aug. 127), and Sinclair opposes Carpenter's "soft and silky brown beard" with James's "skinny Adam's apple that worked up and down" (Carpenter," Aug. 30). Indeed, Carpenter would feel quite at home in such influential novels as Joseph Holt Ingraham's The Prince of the House of David (1856) and Lew Wallace's Ben-Hur: A Tale of the Christ (1880)-both of which were enormously successful and which also depicted the feminised Christ (Gutjahr 159; Theisen 35).

Ingraham describes Jesus as a man with hair that flows over a "high forehead," which makes him "unlike other men" $(98,296)$. Wallace similarly writes that Christ possesses 
a "tearful" and "woman-like face" (523). The film star Mary Magna, Sinclair's incarnation of Mary Magdalene, even describes Carpenter as "a close up from ... "BenHur"' (34). The Rev. John W. Chadwick-in his response to Kate Hampton-also argued that images of Christ were "almost as lackadaisical and gelatinous as the literary Christ in General Wallace's "Ben-Hur"' (qtd. in Hampton 744). Lucius Wolcott Hitchcock's (1868-1942) illustrations that accompany Sinclair's work, moreover, perfectly capture the feminized Carpenter, whom Sinclair presents as "a man in long robes, white, with purple and gold; with a brown beard, and a gentle, sad face" ("Carpenter," Jul. 10). That Sinclair chooses to draw a similarity between James and Carpenter is significant. James obviously cannot be a Christ figure in the novel, but he can be a figure that demonstrates Sinclair's awareness of literary efforts to masculinise Christ.

Thomas De Witt Talmage's From Manger to Throne (1890), for example, highlighted the workingman Jesus by drawing attention to "The boy Carpenter! The boy wagon maker! The boy housebuilder" (Talmage 190). Harry Emerson Fosdick-himself so instrumental in challenging religious fundamentalism in the 1920s-also referred to Jesus as appealing to "all that is strongest and most military in you" (161), and Bruce Barton's The Man Nobody Knows (1925) revealed a muscle-bound Jesus whose "muscles were so strong that when He drove the moneychangers out, nobody dared oppose Him!" (Barton 12). Look forward a generation, and perhaps John Steinbeck does create in men like James the figure of Christ. The Grapes of Wrath (1939) sees Jim Casy take on the role of Christ (Han; Shockley). Casy, like James, is an overall-wearing, working man who possesses "a long head, bony; tight of skin, and set on a neck as stringy and muscular as a celery stalk" (23). He believes that humanity can return again to holiness when "they're all workin' together, not one fella for another fella, but one fella harnessed to the whole shebang" (89).

Sinclair, therefore, does not create in Carpenter a masculinised figure, but I argue that this was a deliberate satirical conception to juxtapose the legacy of the image of the feminised Christ with words and actions that incite violence against him. In the figure of Carpenter, then, Sinclair creates the proverbial wolf in sheep's clothing: he may look like the iconic Son of God of the nineteenth century, but he preaches a message through which Sinclair challenges the established Church, and this is exactly why The Moslem Sunrise found "They Call Me Carpenter" so relevant for their own purposes in America.

The era of the Great Depression was yet to come, but Sinclair also wrote in a socially transformative era, The Jazz Age, or the Roaring Twenties. It saw the arrival of greater social liberalism and sexual freedoms that challenged the conventions of a previous generation. Sinclair reflects this social transformation through the sexualisation of the feminized Christ of the nineteenth century. Carpenter takes on a sexual allure in the later novel They Call Me Carpenter-"this man will make a hit with the ladies ... like the swamis, with their soft brown skins and their large, dark, cow-like eyes!" Sinclair writes (22). If this sexualized interpretation of Jesus had appeared in the serialized story in Hearst's International, then perhaps The Moslem Sunrise would have thought twice about including a review of Sinclair's work. But I propose that Sinclair also became aware that he needed to represent a truer picture of Los Angeles's cultural diversity. Sinclair's additional material in They Call Me Carpenter includes a description of Western City as a city that "brings strange visitors to dwell here; we have Hindoo swamis in yellow silk" (15). Sinclair probably incorporates the legacy of Swami 
Vivekananda (1863-1902) here-a Hindu monk who visited Los Angeles during his tour of America-but the passage could equally represent Sinclair's misunderstanding of cultures. Edward E. Curtis, for example, suggests that, in the context of Los Angeles, "many sources from the late 19th and early 20th centuries did not distinguish among Muslim, Hindi, and Sikh Punjabis" (345). Perhaps Sinclair was guilty of the same misunderstanding and was actually thinking of men like Sadiq in his generalization of "the strange visitors" of Los Angeles (22).

Indeed, Ahmadi Muslims were certainly active in the Los Angeles that Sinclair represented in "They Call Me Carpenter." Each cover of The Moslem Sunrise depicted a map of the United States with sites for mission clearly marked; Los Angeles was one such target. C. F. Sievwright described "the advent in America of Mufti Muhammad Sadiq" and his own work to spread the message of Islam in what he describes as "the DIS-UNITED STATES" (Sievwright "We Must Co-Operate" 144). Sievwright wrote a number of articles for The Moslem Sunrise for which he cited location as Los Angeles (Sievwright "Detroit" 69-70), (Sievwright "Extracts" 192), (Sievwright "Expressions" 226). The Los Angeles Examiner also reported on Sievwright and incorporated him into a larger piece that explored the significance of Ramadan for Muslims (qtd. in TMS "Press Notices" 193). Although no clear evidence exists that Sinclair incorporated Muslims into "They Call Me Carpenter," his description of Christ and associated femininity resembles an article in The Chicago Defender of August 1922 that reported Sadiq's mission work in Chicago. It described Sadiq as looking the part of a prophet because of his "slender mold, with sideburns that grow into a flowing beard of gospel likeness" (Didier 5). Turner even suggests that Sadiq's resemblance to a "biblical prophet" found favour with African Americans (124), but The Chicago Defender was also, I argue, projecting onto Sadiq the feminized Jesus that Sinclair satirized in his rendering of Carpenter-thus revealing a larger cultural connection that is not immediately obvious.

\section{ETHNICITY AND FIGURE OF JESUS}

Perhaps a more pressing issue than Jesus' femininity was his ethnicity. Until the turn of the twentieth century, Jesus was overwhelmingly associated with an Anglo-Saxon identity. First, Catholic immigrants brought with them images of Christ that were derived from the Renaissance; and second, the European marketplace fuelled a national appetite for images of Christ (Blum and Harvey 139-151). Joseph Tissot's The Life of Our Saviour Jesus Christ (1899) assuaged this appetite, and it became a national success owing to a promotional tour of the United States throughout 1897 (Tissot). Tissot's work clearly represented an Anglo-Saxon and feminized Christ, but his Christ bore no real resemblance to the realistic representations of other biblical figures, for example St. Matthew, whom Tissot represented as short-haired, masculine, and of more obviously Middle Eastern appearance (Blum and Harvey 62, 114). Opposition to the white Christ began to gather pace from within America's churches (Blum and Harvey 150). As already alluded to above, "They Call Me Carpenter" was part of a much larger religious literary heritage of the nineteenth century that focussed on the figure of Christ-these works also represented the white Christ. Ingraham's The Prince of the House of David describes Jesus as a "pale and sad" man with eyes "richly brown in hue, and darkly shaded by sable lashes" (296). Wallace's Ben-Hur highlights Jesus' "locks of yellowish bright chestnut hair" and "a face lighted by dark-blue eyes, at the time so soft, so appealing, so full of love" (130). 
41 engages with the whiteness of Christ with the same satiric effect. American literary naturalism has an uneasy relationship with race. Jack London's (1876-1916) writings include language that is unquestionably racist (Reesman), and Frank Norris's antiSemitism in McTeague cannot be ignored (Pizer). Mark Noon has also addressed Sinclair's blatant racism against African American strikers in The Jungle (430-431), and we saw Sinclair employing similar language against Mexicans in "They Call Me Carpenter." That being said, Sinclair's relationship with race-rather like Jack London's -is often contradictory. He also protested against the rise of nativism during the First World War that manifested in a resurgence of groups like the Ku Klux Klan. It saw itself as a protector of American values in its war against those elements that it deemed to be un-American (Lewis and Serbu 144).

In the October issue of Hearst's International, Sinclair uses the Klan to stage a successful rescue of Carpenter from an angry mob who are determined to kill him-thus reimagining Christ's arrest in the Garden of Gethsemane (John 18:3). Billy and others dress up as members of the Klan to carry out their plan. Sinclair alludes to D. W. Griffith's The Birth of a Nation (1915) in a sequence of narrative that sees Billy and Mary acquire the costumes of "a very dull feature picture" that shows "the salvation of our country by the Ku Klux Klan" (Carpenter (Oct. 34). The Birth of a Nation presented the Klan as saviours of American society in their overthrowing of a black militia and its white sympathizers in post-war South Carolina. Indeed, Tom Rice argues that the Klan "utilized The Birth of a Nation ... to define and promote itself within American society" (1-2). The Klan also adopted the image of the white Christ to add legitimacy to their actions as they reacted against non-whites, socialists, communists and immigrants (Blum and Harvey 141). This Christ becomes manifest at the climax of The Birth of a Nation when, with a note of eschatological premillennialism, Christ returns to bless the Klan's victory. Sinclair's incorporation of the Klan into "They Call Me Carpenter" is significant because here the Klan is cleansing America from the very image of Christ that they used to justify their own actions. The tensions and fears of a society suffering from a crisis of post-war xenophobia that targeted those deemed un-American emerge in narrative. “" "Death to all traitors!" ... "Death to all agitators! Death to all enemies of the Ku Klux Klan!"' cry Billy and Mary as they save Carpenter ("Carpenter," Oct. 136).

True, Sinclair does not explicitly argue that Jesus was non-white, but he clearly challenged conceptions of his whiteness throughout a satirical attack upon the protectors of the image of the white Christ. It is through this challenge, I argue, that The Moslem Sunrise found an affinity in Sinclair's work because of its own anti-racist stance (Howell 53). The Moslem Sunrise was certainly aware of the violence that the Klan inflicted upon African Americans. In July 1922, they included a review article of Dr. Frank Crane's (1861-1928)-Presbyterian minister and editor of Current Opinion-in which Crane stated that "the West keep on lynching the black man, while it spoke of universal brotherhood and humanity" (TMS "Awakening" 119). Preceding the review of "They Call Me Carpenter," The Moslem Sunrise also included the following article entitled "Christian Toleration!" in which they highlighted the hypocrisy of the Klan. They reasoned that if the Klan could exist, then there must be an inherent flaw in the way the Church was teaching the message of Jesus, which is exactly the same context from which I argued Sinclair's work emerged.

Thirty lynchings of Negroes by white Christians were recorded in the United States during the first half of 1922 . Some burnt at stake, others put to death. These are the 
wonderful acts of the meek lambs of Jesus. After all a tree is known by its fruits.

(TMS "Toleration" 136)

A generation earlier, the civil rights activist Albion Tourgée attacked the whiteness of Christ in the novel Pactolus Prime (1890). Tourgée wrote that "the 'white' Christ is man's distortion ... I believe the 'white' Christ will continue to dominate the Christian thought, and consequently to mould the public sentiment, of this country" (297-298). Look forward a little further and that same spirit emerged in work of el-Hajj Malik elShabazz (1925-1965), Malcolm X. He argued that black Americans were "taught to worship an alien God having the same blond hair, pale skin and blue eyes as the slavemaster" (257). Referring to the time he spent incarcerated as a young man, Malcolm X argued that “I don't care how tough the convict, be he brainwashed black Christian, or a 'devil' white Christian, neither of them is ready to hear anybody saying Jesus wasn’t white” (286).

\section{PREACHING PROPHETS}

Both Malcolm X and Upton Sinclair, then, were not afraid to challenge cultural orthodoxy, and this same spirit played out in “They Call Me Carpenter." Sinclair's work ends with the reader realising that Billy's experiences had only been a dream, but the cultural history surrounding the story was far from imaginary, particularly to Sadiq and The Moslem Sunrise. In 1922, the work of Upton Sinclair-America's preeminent muckraking author who is often associated with literary naturalism-appealed to a Punjabi missionary who had just brought Ahmadi Islam to America. Through Sinclair's representation of Jesus, Ahmadi Muslims recognised a cultural affinity with an author who had already done so much-through the publication of The Jungle-to challenge the American economic and social order. They each saw in Jesus a human prophet who fought on the side of the dispossessed, who rejected the contemporaneous Christian Church, who stressed human brotherhood, and who challenged those who held power in society. 


\section{BIBLIOGRAPHY}

"Church Has Failed, Says Rev. Pullinger." The Detroit Free Press, January 91922.

"Trying to Make Christian America Mohammedan." The Ogden Standard-Examiner, June 251922.

Abd-Allah, Umar F. A Muslim in Victorian America: The Life of Alexander Russell Webb. Oxford: Oxford UP, 2006.

Arthur, Anthony. Radical Innocent: Upton Sinclair. New York: Random House, 2006.

Barton, Bruce. The Man Nobody Knows. Indianapolis: Bobbs-Merrill, [1925] 1956.

Blum, Edward J., and Paul Harvey. The Color of Christ the Son of God and the Saga of Race in America. Chapel Hill: U of North Carolina P, 2014.

Bourne, Randolph S. “Trans-National America.” The Atlantic Monthly July (1916): 86-97.

Bruns, Roger. Preacher: Billy Sunday and Big-Tme American Evangelism. U of Illinois P, 1992.

Burns, David. The Life and Death of the Radical Historical Jesus. Oxford: Oxford UP, 2013.

Campbell, Donna. Resisting Regionalism: Gender and Naturalism in American Fiction, 1885-1915 Athens: Ohio University Press, 1997.

Channing, William Ellery. A Sermon Delivered at the Ordination of the Rev. Jared Sparks, to the Pastoral Care of the First Independent Church in Baltimore, May 5, 1819 Boston, Mass.: American Unitarian Association, 1819.

---. Two Sermons on Infidelity, Delivered October 24, 1813. Boston: Cummings and Hillard, 1813.

Chicago Daily Tribune. "Christianity Is a Failure Says Sir Conan Doyle: Spiritualism Soon to Sweep the Earth, He Declares." Chicago Daily Tribune, October 20 1919. Accessed

Curtis, Edward E. Encyclopedia of Muslim-American History. New York: Facts on File, 2010.

Debs, Eugene Victor. Labor and Freedom: The Voice and Pen of Eugene V. Debs. P. Wagner, 1916.

Didier, Roger. "Those Who're Missionaries to Christians: Prophet Sadiq Brings Allah's Message into Chicago and Makes Proselytes." The Chicago Defender, August 191922.

Dorrien, Gary J. The Making of American Liberal Theology: Idealism, Realism, and Modernity 1900-1950. Louisville, Ky.: Westminster John Knox, 2003.

Douglas, Ann. The Feminization of American Culture. New York: Knopf, 1977.

Dudley, John. A Man's Game: Masculinity and the Anti-Aesthetics of American Literary Naturalism. Tuscaloosa: University of Alabama Press, 2004.

Elliott, Robin G. "The Eastern European Immigrant in American Literature: The View of the Host Culture, 1900-1930." Polish American Studies 42 (1985): 25-45.

Evening Public Ledger, “Comes to Teach Us Ahmadi." Evening Public Ledger .

February 17, 1920.

Fosdick, Harry Emerson. The Manhood of the Master New York: Association Press, 1919.

Fox, Richard Wightman. Jesus in America: Personal Savior, Cultural Hero, National Obsession. San Francisco, Calif: HarperSanFrancisco, 2005. 
Garvey, Amy Jacques The Philosophy \& Opinions of Marcus Garvey; or, Africa for the Africans, Volumes 1 \& 2 Dover, Mass: The Majority Press, 1986.

GhaneaBassiri, Kambiz. A History of Islam in America: From the New World to the New World Order. Cambridge: Cambridge UP, 2010.

Green, Nile. Terrains of Exchange: Religious Economies of Global Islam. Oxford UP, 2015.

Gutjahr, Paul C. An American Bible: A History of the Good Book in the United States, 1777-

1880. Stanford, Calif.: Stanford UP, 1999.

Hampton, Kate P. "The Face of Christ in Art: Is the Portraiture of Jesus Strong or Weak?" The Outlook 61 (1899): 735.

Han, John J. "Jesus as a Cultural Hero: Steinbeck's Use of the Christ Figure in "the Grapes of Wrath"." The Steinbeck Review 2 (2005): 25-36.

Hearst's International. “Clouds in the East.” Hearst's International, 42 (November 1922): 7.

Higgs, Robert J. God in the Stadium: Sports and Religion in America. Lexington, Ky.: UP of Kentucky, 1995.

Howell, Sally. "Laying the Groundwork for American Muslim Histories: 1865-1965." The Cambridge Companion to American Islam. Ed. Hammer, Juliane and Omid Safi. Cambridge: Cambridge UP, 2013.

Ingersoll, Robert G. The Works of Robert Ingersoll, Volume 1 New York: The Dresden Publishing Company, 1902.

Ingraham, Joseph Holt. The Prince of the House of David; or, Three Years in the Holy City New York: Pudney and Russell, 1858.

Irving, Katrina. Immigrant Mothers: Narratives of Race and Maternity, 1890-1925. Chicago: U of Illinois $P, 2000$.

Jefferson, Thomas. The Life and Morals of Jesus of Nazareth (the Jefferson Bible). Vol. 1: Library of Alexandria, 1942.

Jung, Dietrich "The Origin of Difference: Edward Said, Michel Foucault, and the Modern Image of Islam." Islam in the Eyes of the West: Images and Realities in an Age of Terror. Ed. Ismael, Tareq Y. and Andrew Ripon. London: Routledge, 2010.

Kallen, Horace M. “Democracy Versus the Melting-Pot, Part 2" The Nation 100 (1915): 217-220.

Knight, Mark and Thomas Woodman, "The Word in the World: An Introduction." Biblical Religion and the Novel, 1700-2000. Ed. Mark Knight and Thomas Woodman. Burlington, VT.: Ashgate Publishing Company, 2006. 1-12.

Leinenweber, Charles. "The American Socialist Party and "New Immigrants"." Science and Society 32 (1968): 1-25.

Lewis, Michael, and Jacqueline Serbu. "Kommemorating the Ku Klux Klan." The Sociological Quarterly 40 (1999): 139-58.

Link, Eric Carl. "Defining American Literary Naturalism." The Oxford Handbook of American Literary Naturalism. Ed. Keith Newlin. Oxford: Oxford U P, 2011.71-91.

McKanan, Dan. "The Implicit Religion of Radicalism: Socialist Party Theology, 1900-1934." Journal of the American Academy of Religion 78 (2010): 750-89.

McLoughlin, William G. Revivals, Awakenings, and Reform: An Essay on Religion and Social Change in America, 1607-1977. Chicago ; London: U of Chicago P, 1978. 
Melville, Herman. Moby Dick; or, the Whale New York: Harper \& Brothers, 1851.

Nichols, Stephen J. Jesus Made in America: A Cultural History from the Puritans to "the Passion of the Christ." InterVarsity Press, 2009.

Noon, Mark. "It Ain't Your Color, It's Your Scabbing": Literary Depictions of African American Strikebreakers." African American Review 38 (2004): 429-439.

Obama, Barack. Remarks by the President on a New Beginning. 2009. https:// www.whitehouse.gov/thepress-office/remarkspresidentcairo-university-6-04-09. Accessed October 142006.

Pizer, Donald. American Naturalism and the Jews: Garland, Norris, Dreiser, Wharton, and Cather. Urbana: U of Illinois P, 2008.

Prothero, Stephen R. American Jesus: How the Son of God Became a National Icon. New York: Farrar, Straus and Giroux, 2003.

Putney, Clifford. Muscular Christianity: Manhood and Sports in Protestant America, 1880-1920. Harvard UP, [2001] 2009.

Rauschenbusch, Walter. Christianity and the Social Crisis. New York: The MacMillan Company, 1907. Renan, Ernest. Renan's Life of Jesus. Trans. Hutchinson, William G. London: Walter Scott, 1897. Reesman, Jeanne Campbell. Jack London's Racial Lives: A Critical Biography. Athens: U of Georgia P, 2011.

Rice, Tom. White Robes, Silver Screens: Movies and the Making of the Ku Klux Klan. Bloomington, Indiana: Indiana UP, 2015.

Scott, Derrick. "What a Beating Feels Like: Authorship, Dissolution, and Masculinity in Sinclair's The Jungle." Studies in American Fiction 23 (1995): 85-100.

Shockley, Martin. "Christian Symbolism in the Grapes of Wrath." College English 18 (1956): 87-90. Sievwright, C. F. "Expressions of Appreciation.” The Moslem Sunrise April and July (1923).

---. "Extracts from the Holy Quran (Moslem Bible)." The Moslem Sunrise April and July (1923).

---. “In Praise of Detroit.” The Moslem Sunrise January (1922).

---. “We Must Co-Operate.” The Moslem Sunrise October (1922).

Sinclair, Upton. The Cry for Justice: An Anthology of the Literature of Social Protest; the Writings of Philosophers, Poets, Novelists, Social Reformers, and Others Who Have Voiced the Struggle against Social Injustice. New York: Upton Sinclair, 1915.

---. The Jungle. New York: Doubleday, Page \& Company, 1906.

---. A Personal Jesus. Portrait and Interpretation. London: George Allen \& Unwin, 1954.

---. Samuel the Seeker. London: John Long Limited, 1910.

---. "They Call Me Carpenter." Hearst's International July (1922): 8-13 \&114-18.

---. "They Call Me Carpenter." Hearst's International August (1922): 22-30 \& 126-128.

---. "They Call Me Carpenter." Hearst's International September (1922): 39-54 \& 106-07.

---. "They Call Me Carpenter." Hearst's International October (1922): 31-35 \& 136-40.

---. They Call Me Carpenter: A Tale of the Second Coming London: Boni and Liveright, 1922. 
Sinclair, Upton, and John Boyd. "What Life Means to Me." Cosmopolitan 41 (1906): 591-595.

Soulen, Richard N., and R. Kendall Soulen. Handbook of Biblical Criticism. Louisville, Ky.: Westminster John Knox Press, 2011.

Southern Herald, “The Amazing Spread of Islam." The Southern Herald, February 16, 1912. Spellberg, Denise A. Thomas Jefferson's Qur'an Islam and the Founders. New York, NY: Vintage, 2014. Stead, William. If Christ Came to Chicago!: A Plea for the Union of All Who Love in the Service of All Who Suffer London: The Review of Reviews, 1894.

Steinbeck, John. The Grapes of Wrath. London: Pan Books, [1939] 1980.

Strauss, David Friedrich The Life of Jesus: Critically Examined. Trans. Eliot, George. London: Swan Sonneschein \& Co, , 1902.

Talmage, Thomas De Witt. From Manger to Throne: Embracing a New Life of Jesus the Christ and a History of Palestine and Its People. Historical Publishing Company, 1893.

Theisen, Lee Scott. "“My God, Did I Set All of This in Motion?" General Lew Wallace and BenHur." The Journal of Popular Culture 18 (1984): 33-41.

Tissot, James Jacque Joseph The Life of Our Saviour Jesus Christ: Three Hundred and Sixty-Five Compositions from the Four Gospels with Notes and Explanatory Drawings Toronto: George N. Morang \& Company, 1899.

The Moslem Sunrise. "The Awakening of the West." The Moslem Sunrise July (1922).

---. "Christian Toleration!" The Moslem Sunrise October (1922).

---. "Crescent or Cross? A Negro May Aspire to Any Position under Islam without Discrimination." The Moslem Sunrise October (1923): 263.

---. "I Am a Moslem." The Moslem Sunrise October (1921).

---. "If Jesus Comes to America." The Moslem Sunrise April (1922): 85-86.

---. "Jesus and the Modern Christians." The Moslem Sunrise October (1922): 137.

---. "Jesus Was Crucified, but Did Not Die on the Cross (a Survey of the Literature on the Subject)." The Moslem Sunrise July (1922): 108.

---. "Muhammadan Faith Explained." The Moslem Sunrise July (1922): 118.

---. "Press Notices." The Moslem Sunrise April and July (1923).

---. "Significant Sayings of the Famous Men of the Day." The Moslem Sunrise October (1922): 152.

---. "Significant Sayings of the Famous Men of the Day." The Moslem Sunrise April (1922): 98.

---. "Some Appreciations." The Moslem Sunrise 19 (1921).

---. "True Salvation of the American Negroes." The Moslem Sunrise October (1923): 267.

Tourgée, Albion W. Pactolus Prime. New York: Cassell Publishing Company, 1890.

Trump, Donald J. Donald J. Trump Statement on Preventing Muslim Immigration. 2015. https:// www.donaldjtrump.com/press-releases/donald-j.-trump-statement-on-preventing-muslimimmigration. Accessed October 142006.

Turner, Richard Brent. Islam in the African-American Experience. Bloomington, Ind.: Indiana UP, 2003. 
U.S. Department of Labor. Immigration Laws (Act of February 5, 1917): Rules of May 1, 1917.

Washington: Government Printing Office, 1917.

Wallace, Lew. Ben-Hur: A Tale of the Christ New York: Harper \& Brothers Publishers, 1887.

Webb, Mohammed Alexander "The Spirit of Islam." The World's Parliament of Religions. Ed. Henry, John. Chicago: The Parliament Publishing Company, 1893.

Wilson, Christopher P. The Labor of Words: Literary Professionalism in the Progressive Era. Athens: U of Georgia P, 1985.

X, Malcolm. The Autobiography of Malcolm X. London: Penguin Modern Classics [1965] 2001.

\section{NOTES}

1. The Moslem Sunrise was and continues to be published every quarter, and-apart from a brief period in the late 1920s-remains in publication. This paper, however, only refers to The Moslem Sunrise at its conception in the early twentieth century. It does not refer to The Muslim Sunrise today or the present Ahmadi community in America.

\section{ABSTRACTS}

In 1920, Mufti Muhammad Sadiq (1872-1957) arrived in America to spread the message of Islam. Two years later, he founded The Moslem Sunrise. The October 1922 issue included a review of Upton Sinclair's (1878-1968) serialized story “They Call Me Carpenter.” In Sinclair's work, Jesus, or Carpenter, returns to live amongst modern Americans. This article explores the theological and cultural contexts that led The Moslem Sunrise to find an affinity in Sinclair's work. It explores how and why The Moslem Sunrise and Sinclair each addressed the Christology of a human Jesus, the perceived failure of the Church to teach his social gospel, the concept of human brotherhood, and the perceived need to masculinise religion-and even Jesus himself and his associated ethnicity. It reveals a previously unacknowledged relationship between Islam and Sinclair and demonstrates how quite different processes can sometimes lead to unity and to a shared direction.

\section{INDEX}

Keywords: American Islam, American Christianity, Early twentieth-century literature, American Literary Naturalism, Jesus of Nazareth, Upton Sinclair, Mirza Ghulam Ahmad, Mufti Muhammad Sadiq, The Moslem Sunrise 